rev.relac.int.estrateg.segur.11(2):49-74,2016

\title{
POPE FRANCIS, CLIMATE CHANGE AND THE ENVIRONMENTALISM OF THE POOR*
}

\author{
Marina Malamud**
}

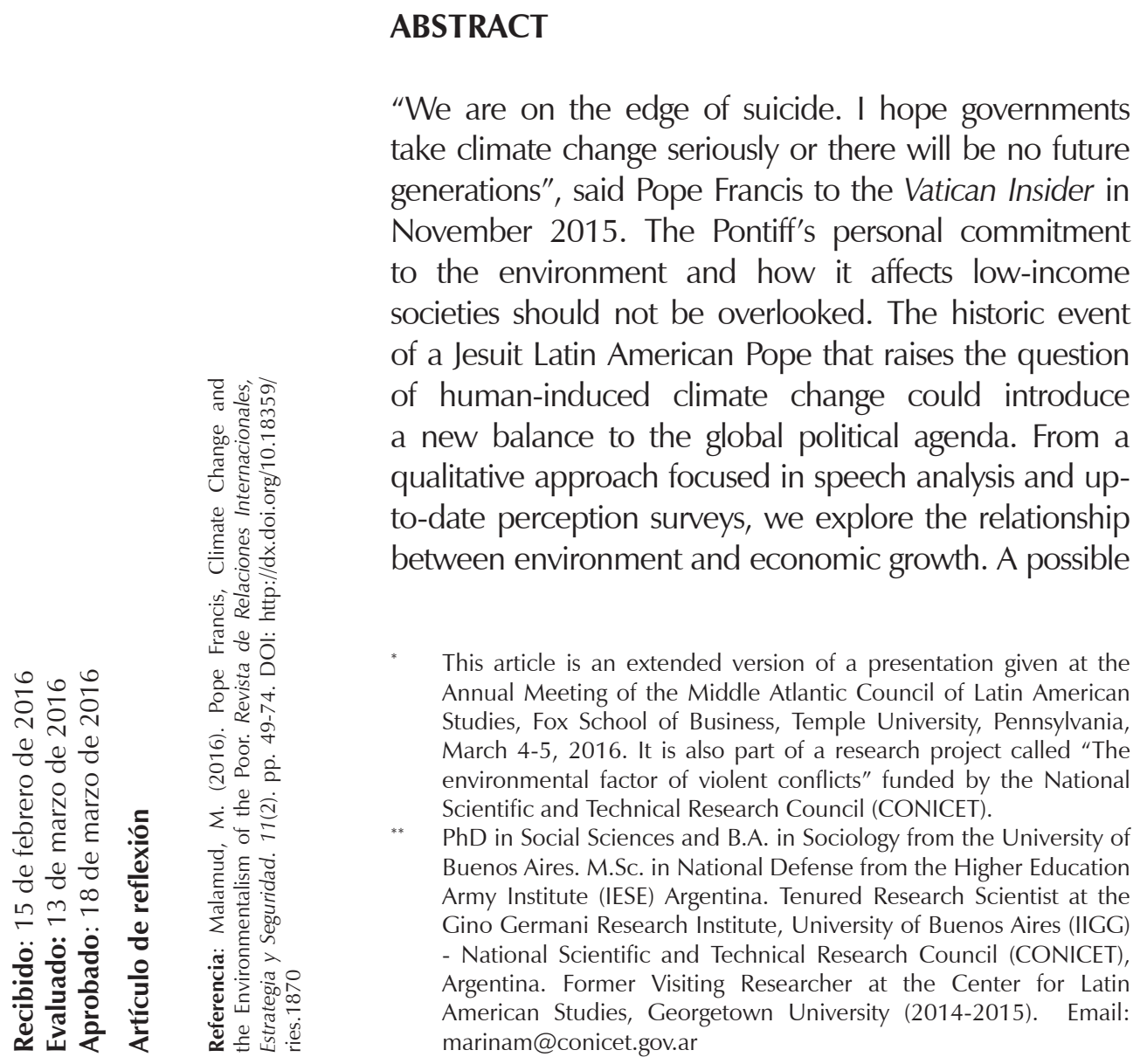


conceptualization of the Pope's position can be associated with the environmentalism of the poor. This approach is based on environmental justice prerogatives as a response to unequal economic exchange between nations. Latin America is particularly exposed to the consequences of climate change and that affects the existing volatile political stability and prospects for a sustainable development. We argue that climate change exceeds scientific and economic positions; it is ultimately a moral consideration.

Key Words: Climate Change; Latin America; Public Opinion.

\section{EL PAPA FRANCISCO, EL CAMBIO CLIMÁTICO Y EL ECOLOGISMO DE LOS POBRES}

\section{RESUMEN}

"Estamos al borde del suicidio. Espero que los gobiernos tomen en serio el cambio climático o no habrá generaciones futuras", dijo el Papa Francisco al Vatican Insider en noviembre de 2015. El compromiso personal del pontífice con el medio ambiente y cómo afecta a las sociedades de bajos ingresos no debe pasarse por alto. El evento histórico de un Papa jesuita de América Latina que plantea la cuestión del cambio climático inducido por el hombre puede introducir un nuevo equilibrio en la agenda política mundial. Desde un enfoque cualitativo centrado en el análisis del discurso y encuestas de opinión actuales, exploramos la relación entre medio ambiente y crecimiento económico. Una posible conceptualización de la posición del Papa se puede asociar con el ecologismo de los pobres. Este enfoque se basa en prerrogativas de justicia ambiental como una respuesta al intercambio económico desigual entre las naciones. América Latina está particularmente expuesta a las consecuencias del cambio climático y eso afecta la existente estabilidad política volátil y las perspectivas de desarrollo sostenible. Se argumenta que el cambio climático supera las posiciones científicas y económicas; es en última instancia una consideración moral.

Palabras Clave: Cambio Climático; América Latina; Opinión Pública

\section{O PAPA FRANCISCO, AS ALTERAÇÕES CLIMÁTICAS E O ECOLOGISMO DOS POBRES}

\section{RESUMO}

"Estamos à beira do suicídio. Espero que os governos tomem as mudanças climáticas a sério ou não haverá gerações futuras", disse o Papa Francisco ao 
Vatican Insider, em novembro de 2015. O compromisso pessoal do pontífice para com o meio ambiente e como isso afeta as sociedades de baixa renda não deve ser negligenciado. O evento histórico de um Papa jesuíta Latino Americano, que levanta a questão da mudança climática induzida pelo homem pode introduzir um novo equilíbrio para a agenda política global. A partir de uma abordagem qualitativa centrada na análise de discurso e pesquisas de percepção pública atuais, vamos explorar a relação entre ambiente e crescimento econômico. Uma possível conceituação da posição do Papa pode ser associada com o "ecologismo" dos pobres. Esta abordagem baseia-se em prerrogativas da justiça ambiental como uma resposta ao intercâmbio econômico desigual entre nações. América Latina é particularmente exposta às consequências das alterações climáticas e afeta a estabilidade política volátil existente e as perspectivas para o desenvolvimento sustentável. Argumentamos que a mudança climática é superior as posições científicas e econômicas; em última instância é uma consideração moral.

Palavras-Chave: Mudança Climática; América Latina; Opinião Pública.

\section{Introduction}

The fossil fuel-driven economy has had several effects on the environment such as a more frequent incidence of weather-related extreme events, global warming, and the increase of greenhouse gas emissions. As a result, environmental activists, scientists, politicians, NGOs, and businessmen have different perceptions regarding how to interpret the impact of these effects. The question is to what extent these effects threaten the human being's livelihood on the planet. The debate is undoubtedly fervent and endless. What has raised major concern over the past decade is, however, that there are visible environmental consequences that besides disagreements on causes, they actually endanger our near future.

Climate change is not an isolated occurrence; it is part of the relationship between developed and less developed countries and the parameters that lead the interaction between society and the natural environment. In this landscape, we consider as a premise that climate change surpasses scientific facts, financial optimization of procedures and political stances: it is, in the end, a moral debate. For this reason, we consider that the intervention of a religious leader can have an impact on the global political agenda and public opinion'.

It is important to highlight that the Pope not only speaks for the moral values of the Catholic Church; he is the highest authority of the Vatican as well. 
The Intergovernmental Panel on Climate Change (IPCC) is the world's leading organization in the field ${ }^{2}$, even though it is a mixed intergovernmentalscientific institution. In its main report, it is reflected that:

Each of the last three decades has been successively warmer at the Earth's surface than any preceding decade since 1850 . The period from 1983 to 2012 was likely the warmest 30-year period of the last 1400 years in the Northern Hemisphere, where such assessment is possible (medium confidence). The globally averaged combined land and ocean surface temperature data as calculated by a linear trend show a warming of 0.85 [0.65 to 1.06 ] ${ }^{\circ} \mathrm{C}$ over the period 1880 to 2012, when multiple independently produced datasets exist. (IPCC,2014, p.2)

The outcome of climate change is considered as a result of human activity:

Anthropogenic greenhouse gas emissions have increased since the pre-industrial era, driven largely by economic and population growth, and are now higher than ever. This has led to atmospheric concentrations of carbon dioxide, methane and nitrous oxide that are unprecedented in at least the last 800,000 years. Their effects, together with those of other anthropogenic drivers, have been detected throughout the climate system and are extremely likely to have been the dominant cause of the observed warming since the mid-20th century. (IPCC,2014, p.4)

There are several statistics that demonstrate the effects of climate change together with an environmentally unsustainable development architecture at a global level. In 2012, 3.7 million deaths were caused byambientair pollution. Around $88 \%$ occurred in low and middle income countries that represent $82 \%$ of the world population (WHO,2012). The World Health Organization's standard for a safe annual average is $10 \mu \mathrm{g} / \mathrm{m}^{3}$. At the top of this list are India and Pakistan. As an example, every day the residents of New Delhi breathe air contaminated by fine particles at a concentration of $153 \mu \mathrm{g} / \mathrm{m} 3$. In Beijing, around 1.6 million people are killed by breathing bad air annually (The Guardian, 2015, December $\left.2^{\text {nd }}\right)$. It is observed that only $12 \%$ of the people living in metropolises reporting on air quality reside in cities that comply with $\mathrm{WHO}$ guideline levels. Although as individuals there is little to be done,

The IPCC was established by the United Nations Environment Program (UNEP) and the World Meteorological Organization (WMO) in 1988 to produce studies in climate change and provide assessment to governments. 
some cities like Copenhagen and Bogotá are mentioned in the report as having improved air quality by promoting urban public transportation, walking, and cycling (WHO, 2014).

The trend in terms of weather disasters is also increasing. There is a rise in the number of floods that accounts for 47 \% (1995-2005) of the total disasters affecting 2.3 billion people (the majority of whom live in Asia). Storms were less frequent but were of the deadliest type killing more than 242.000 people in the past 21 years occurring primarily $(89 \%)$ in lower-income countries. Among the most affected countries in terms of weather related disasters per 100.000 inhabitants are China, India, and Brazil; in relative mortality terms (1995-2005) the only Latin American country mentioned is Venezuela, which holds the second largest number of deaths per million inhabitants after Myanmar (UNISDR, 2015).

In general, climate change is still a controversial issue that involves the credibility of some scientific research. The majority of scientific institutions worldwide reveal that there is enough evidence of the climate system's warming:

Earth-orbiting satellites and other technological advances have enabled scientists to see the big picture, collecting many different types of information about our planet and its climate on a global scale. This body of data, collected over many years, reveals the signals of a changing climate. The heat-trapping nature of carbon dioxide and other gases was demonstrated in the mid-19th century. Their ability to affect the transfer of infrared energy through the atmosphere is the scientific basis of many instruments flown by NASA. There is no question that increased levels of greenhouse gases must cause the Earth to warm in response. (NASA, 2015, December $4^{\text {th }}$ )

The mainstream of scientists working on climate issues say that humancaused climate change is a fact. Both surveys and empirical assessments of peer-reviewed literature suggest that the consensus reaches approximately 97\% of researchers (Myers, Maibach, Peters \& Leiserowitz, 2015). At an institutional level, the Governor's Office of Planning and Research at the US State of California published a list of scientific organizations that support global warming theory. Among the nearly 200 institutions are the National Academies of Sciences of Mexico, Peru, Bolivia, Brazil, Nicaragua, US, Canada, Armenia, UK, Ireland, Jordan, South Africa, Nigeria, Malaysia, Bulgaria, Mozambique, Tanzania, Turkey, Portugal, Russia, South Korea, Netherlands, and Israel (OPRCA,2016).

At the same time, the confusing landscape of technical definitions affects public opinion that is biased regarding the subject. People's considerations vary according to whether or not it is a scientifically accepted fact and whether or not affects their personal experiences. 
If the topic is considered as too far away or too complex to grasp, the public interest tends to drop. To make matter worse, there is still an erratic awareness in the academic, political, and business sectors in terms of bringing the subject to the mass media.

If we think about it from a pragmatic level, accepting climate change is finally a call for new ways of doing business and a political commitment for government leaders. In particular, it is not irrelevant in terms of the asset allocation and long-term public policies that will be needed to tackle the already visible consequences. In other words, it definitely affects many companies' business models and government's agendas.

It can be assumed that $97 \%$ of agreement among scientists and no other results to counter-fact the climate change theory (so far) is enough to consider this subject matter as relevant. In this paper we relativize the importance of the debate over what caused global warming. Instead, we transversally analyze climate change as a scientific fact, as a consequence of an environmentally unsustainable industrialization that led to the current economic growth and as moral stance. The main units of analysis include the mainstream of the scientific community working on this field, examples of the corporative sector committed to clean energy developments, and the Pope's political action as the most important representative of the Catholic Church.
In particular, the influence that the first Latin American Pope in the history of Catholicism has already had on public opinion is of particular significance to our study since we argue that climate change is mainly a moral discussion.

As a starting point, Pope Francis released an Encyclical Letter in 2015 called Laudato Sí (Be Praised to You) were several considerations in climate change, the market, and poverty were presented. It can be considered as part of the Vatican's commitment against climate change. The document points out that the environmental degradation impacts the life of the poorest in particular. Contamination, natural catastrophes, diseases, wars, and forced migrations are some of the most evident consequences. To solve the problem, world leaders are requested to find a way to slow down economic growth and support an energetic revolution by abandoning the use of fossil fuels. Consequently, developed countries should comply with an agreement to technically and financially assist poorer nations to achieve such goals (The Washington Post, 2015, November $30^{\text {th }}$; Infobae, 2015, December $15^{\text {th }}$ ). In the following paragraphs, we analyze the document and its weight in the public opinion through existing polls and surveys from a qualitative approach.

We divided the argument in three sections: first, the emergence of environmental research as a major topic and the conditions that any 
environmental issue would fulfill to be considered an actual threat. The second section is focused in the moral discussion of climate change and the implication of Pope Francis' political commitment to raise the concern over vulnerable populations. In that sense, we infer that the pontiff's intervention on the topic can be framed as part of the environmentalism of poor as a conceptual framework. As a final point, we argue that the cost that environmental degradation has on low and middle income countries is related to an ever increasing gap between developed and developing nations reflected as the "North-South dichotomy". In that sense, we explore current initiatives focused on lowering the effects of climate change on less industrialized economies such as those in Latin America.

\section{Cultural and Scientific Grounds of Environmental Awareness.}

Ever since the oil crisis in the early 1970s, the dependency of industrialized countries on fossil fuels led to the systematic study of environmental issues. Of particular significance became air pollution and water contamination as a result of the human overuse of renewable and non-renewable resources. Thus, the social sciences began to analyze environmental issues, from the inability of the ecosystem to absorb the waste of human activity to the importance of protecting the natural environment. In that sense, the mainstream in environmental sociology identifies three socio-historical phases: the energy crisis of 1973-1974 that highlights the dependency of industrialized countries on fossil fuels with the inability to generate efficient energy systems and the scarcity of resources; the greenhouse gas effect crisis caused by carbon dioxide emissions; and the rise of mega hazards as a part of weather-related catastrophes. (Dunlap, Michelson \& Stalker 2002, p.13).

After the energy crisis in the 1980s, a second wave of more complex environmental problems were linked to the destruction of forests, loss of biodiversity, acid rain, and global warming. It is basically the result of the rapid increase of carbon dioxide (CO2) in the atmosphere mainly formed by the burning of fossil fuels (basic for the current industrial model). The concentrated heat rises the $\mathrm{CO} 2$ atmospheric temperature; in other words, it creates a greenhouse gas effect. The warming is then generated by the overuse of the atmosphere as waste depository of economic activity, producing changes that make our planet less likely to live not only for humans but for other species as well (Dunlap, et al. 2002, p.13).

The third wave, although less detectable from direct human perception, is related to massive environmental risks (mega-hazards) that are harmful to large portions of territory with the 
potential to affect future generations (like the toxic pollution of natural resources). During this last phase of environmental problems, it became clear within the global political agenda that environmental problems need inter-state solutions. In other words, current environmental crises demand to "think globally and act locally" (Beck, 2004, p.157).

In terms of the perceptions of scientists, although (as already mentioned in the introduction) $97 \%$ of them approve current results of climate change research, there is a small number of researchers that disagree. In this case, the existence of global warming is denied and/or the fact that is humaninduced. For instance, John Coleman, co-founder of Weather Channel, is quoted in the online newspaper Tech Times (2015, October 27) alleging that all about climate change is just a political tool; the ocean is not rising significantly, the ice melting is not a fact, and the strength and occurrence of storms are diminishing. Most of his views are based on an anti-Panel on Climate Change called Nongovernmental International Panel on Climate Change as a counter-action of the Intergovernmental Panel on Climate Change (IPCC).

The 1973 Nobel laureate physicist Ivar Giaever also opposed the scientific consensus over global warming and called it "the new religion". In disagreement with the American Physical Society`s statement "the evidence is incontrovertible: global warming is occurring", the scientist maintained that the climate has been amazingly stable for the last 150 years and resigned to his honorary position in that institution (The Telegraph, 2011, November 25 th $)$.

The Heartland Institute, a NonProfit Organization, in line with the above poses a prerogative towards an academic and political response against IPCC's alarmism and their "lobby groups". It is therefore stated in an article about disagreement on climate change that the only consensus among scientists is that human activities can affect local climate so the sum of those effects could hypothetically rise to become observable on the Earth. To what extent these consequences are part of the natural variability or outside the expected range is the remaining question (Isdo, Carter \& Singer, 2015).

Although these counter-arguments could potentially have a valid point, most experiments conducted so far have ended in analogous conclusions. As mentioned in the introduction, the vast majority of the national academies of science in the world agree with the theory of global warming. In this landscape, the fact that the topic is sensitive raises another question, and that is why after many systematic researches and similar findings it is still so controversial.

A possible answer can be induced by Riley Dunlap's (2002) contribution to 
the societal-environmental intersection: the main argument is that social sciences (sociology in particular) have been deeply influenced by the Western culture that has an anthropocentric view. For a long time, humans were seen separate and above the rest of nature. Scientific and technological advances based on the use of nature in the industrial age allowed economic growth and an optimistic belief in progress. The shift towards urbanism reinforced the idea that societies were becoming independent from the natural environment. As a result, the major assumption until recently was that industrialized societies were exempt from the limits of nature (Dunlap, 2002, p.18). In that sense, the acceptance of the human being's effect on the ecosystem transforms the ongoing paradigm as a collapse of the anthropocentric view of the environment.

From a political focus the Director of the Yale Program on Climate Change Communication Anthony Leiserowitz highlighted at an MIT Conference two years ago that the reason of the uninterrupted controversy is that some scientists and advocators funded by a number of companies are raising misinformation to create confusion on public perceptions. Thus, the current situation is equivalent to the "tobacco wars" some decades ago: tobacco companies funded scientists to promote the question if smoking was prejudicial or not (MIT CoLab Conference, 2014). Once again, if the public perception is that scientists have no agreement on a specific issue, people tend to overlook the subject and keep doubts about it or just reject it until an unambiguous concept is reached.

The above takes us to another consideration: what are the conditions to identify a valid environmental problem. First of all, it is infrequent to find an environmental problem that does not have its origins in a scientific investigation. The structures that support science are the ones responsible to place them over other social problems. However, by definition, there is a scientific uncertainty that prevents unequivocal evidence or the possibility to give unconditional proof of findings. This situation allows argumentations inside and outside of science to assert a situation as alarming or deny it (Hannigan, 2009, pp. 141-145). Fluctuation in people's considerations are directly related to scientific consensus. Those who think climate change is induced by human activity not only are more supportive with mitigation initiatives but they tend to have behavioral changes like reducing energy usage (Brenkert-Smith, Meldrum \& Champ, 2015, p. 342).

An event can be transformed into an extensively accepted environmental problem when it captures the media attention, involves a government organization, it is a pattern rather than a single event, and is related to the personal interests of a large number of people. Nevertheless, to survive in the political community, it has to propose neutral solutions rather than 
an ideological nature. A problem framed in utilitarian terms has greater acceptance. In this regard, when it intersects financial interests it will be more likely to be taken as a priority by the international community than those built on moral justifications (Hanningan, 2009, pp.110-113).

At a macro-level, given the importance of the relationship between human beings and their surroundings, the environment cannot be an objective concept. People's subjective perceptions impose a direction and give meaning to the environmental component. So the study of emerging conflicts related to the environment needs to acknowledge the perceived, defined, and acted upon attitudes of individuals (Dunlap, et al., 2002, p. 14). Interpretative social sciences have therefore a lot to offer in environmental research by asking alternative questions and promoting concepts for policy purposes (Blue, 2015).

A sociological approach of climate change should unavoidably take into account the value-oriented social action. That is why polls and surveys are included in this work: to explain how climate change and environmental degradation is reflected in people's considerations. Some variables such as political stances, values and basic emotions entail the most significant incidence in people's responses to the topic as we will see next.

According to the Global Risks Report (WEF, 2016, p.3) environmental worries have been at the forefront of "perceived risks", particularly those related to climate change. However, it is particularly remarkable that the "likelihood" of these events had an even greater presence in the survey. Out of the ten most important risks (large scale involuntary migration; extreme weather events; failure of climate-change mitigation; interstate conflict; natural catastrophes; failure of national governance; unemployment or underemployment; data fraud or theft; water crises; and illicit trade) three are related to the environment (WEF, 2016, p.3). This is just a sample of the importance that environmental issues have in the global public opinion.

Survey respondents identified as the top five main risks for the next decade: water crises (39.8\%) as the highest single risk, followed by failure of climate-change mitigation (36.7\%), extreme weather events (26.5\%), food crises (25.20\%), and profound social instability (23.30\%), all somehow related to environmental problems (WEF, 2016, p.13) $)^{5}$. These risks could also be grouped as one: for example,

Respondents were asked to select up to five risks of highest concern in this time frame. The percentage indicates the share of respondents who selected the specific global risk among the five risks of highest concern (WEF, 2016 p.13). 
water crisis has a direct impact on food crises, social instability and involuntary immigration.

In Latin America in particular, water is the key variable of its economic competitiveness. The reason is its reliance in hydroelectric sources for energy production and an export-based development model focused in mining and agriculture (all of the above uses immense quantities of water). Although Latin America represents around 8\% of the world's population, it holds $31 \%$ of the planet's fresh water resources (Moreno, 2010, p.120). However, there has already been a need to cut power generation at hydroelectric complexes such as in Brazil in 2001 and Chile during the drought in 2008. In 2009, major cities in Venezuela, Ecuador, Colombia, and Paraguay were forced to ration water, cut electricity generation, or both (Moreno, 2010, p. 121). All of the above due to the mismanagement of this source and the new climate volatile pattern.

The survey conducted by the Pew Research Center (2015) in 40 nations presents general conclusions in what the world thinks about climate change: first, that the concern is particularly important for Latin American and sub-Saharan Africans; whereas North Americans and Chinese (that hold the highest overall carbon dioxide emissions) are less concerned; second, climate change is not seen as a distant threat, although this view is particularly common in Latin America. In Brazil,
90\% responded that climate change is harming people now; third, drought is at the top of the list in climate events equally important in Latin America and Africa; fourth, a median of 54\% agree with a statement saying that rich countries like the U.S., Japan, and Germany should do more than developing countries because they have produced most of the global greenhouse gas emissions, whereas a median of $38 \%$ say that developing countries should do as much as rich countries since they will produce most of the world's greenhouse gas emissions in the future (Pew, 2015).

It is clear that weather-related events are almost at the top of the list in people's concerns all over the world. The exposure to climate volatility and natural hazards are the same for developing and developed nations. An important difference is given in people's perceptions of the actual threat in relation to their personal experience. It can be inferred by the aforementioned surveys that citizens from industrialized economies perceive the topic as more distant, since institutional weakness and their government's capacity to achieve climate mitigation is not a concern.

As a final point, apart from the differences between countries, value orientation was also found as a significant proxy in the subject. A multilevel analysis conducted in a 47 countries indicates that concern for global warming is stronger the 
more often a person attends religious services. Additionally, self-declared supporters of values associated with a post-materialist ideology demonstrated a higher concern over global warming than materialists (Kvaløy, Finseraas \& Listhaug, 2012, pp.16-17).

Additionally, a more recent research found that emotions play an equally important role (50\% of the variance) as ideologies. Discrete emotions were the strongest predictors of policy support in global warming. Worry in particular was the single most important emotion and not fear that could be intuitively associated with climate change (Smith \& Leiserowitz, 2014, p.943). The correlation between values and emotions with the opinion and attitudes towards the subject is an indicator of our premise: climate change is primarily a moral dialogue.

\section{A Popular Environmentalism from Latin America to the World.}

The 2015 meeting in Paris called COP21 launched twenty years in World Climate Change Summits organized by the United Nations (COP1). It is the largest global climate change initiative in the world. In twenty years of annual meetings on climate change, there were non-binding declarations that have focused on two issues: reducing carbon emissions and thereby keeping the increase in temperature by two Celsius degrees. One of the questions that arose in 2015 was how far progress has been made in promoting sustainability since the first UN summit on global warming in Berlin (COP1) through the Kyoto Protocol in 1997 to the present. In addition, and more important, it was questioned to what extent there is enough willingness from more industrialized countries to make a long term commitment. In pragmatic terms, that means promoting the investment in adaptation and mitigation measures to tackle climate change in developing nations.

This last Conference of the Parties reached an agreement based on mitigation, adaptation, and political commitment to reduce the greenhouse gas emissions to keep the world's temperature below $2^{\circ} \mathrm{C}$ with regard to pre-industrial levels. In its Article number 54 it is also stated that developed countries keep their current objective until 2025 in adaptation and transparency efforts, and a new standard of 100.000 million dollars annually should be achieved to assist developing countries (COP21, 2015) ${ }^{6}$.

\footnotetext{
6 In this occasion, a joint statement released by the Governments of the United States of America, Canada, Denmark, Finland, France, Germany, Ireland, Italy, Sweden, Switzerland, and the United Kingdom announced a contribution of \$248 million USD to the Least Developed Countries Fund, hosted by the Global Environment Facility (U.S. Department of State, 2015, November 30 ${ }^{\text {th }}$ )
} 
For the inauguration of the COP21 the Vatican was also represented. But more importantly, the Pope decided to release the Encyclical Letter Laudato Sí. On care for our common home (2015) entirely dedicated to environmental considerations and development. The Letter was published in June, before the meeting was taking place, so that it could potentially have some impact in the event. It addresses different concerns as to "the harm" that humans have induced in the "sister earth". The guiding principles are taken from Saint Francis of Assisi in terms of the inseparable bond between nature, justice for the poor, and commitment with society and peace. We summarized the five main ideas of the document as follows:

1. Pollution and the accumulation of millions of tons of waste that is non-biodegradable and toxic are filling the earth. The problem is linked to a non-recycling culture: the industrial system has not developed a circular model of production capable of preserving natural resources by reusing waste.

2. Climate change is a global problem but it specially impacts developing countries. An important amount of the poor live in places affected by global warming and their means of survival depend on eco-systemic services (agriculture, fisheries, forestry). They do not have any other financial activity or resources that would help them adapt to climate change.
3. The land of the Southern poor is fueling the development of richer countries with a system of commercial relations that is "structurally perverse". As a result, there should be differentiated responsibilities in reducing greenhouse emissions from countries that are more powerful and pollute the most. Making radical decisions to reverse the trend of global warming should include the development of poorer countries as an overall approach. Also, more efficiently organized international institutions empowered to impose sanctions are needed.

4. Technological development has to be coupled with human responsibility, values, and conscience. A technocratic view of society promoted the idea of an infinite growth. The natural environment is a collective good and a patrimony and responsibility of everyone, so it should be administrated not taken as a possession or seen as a source of unlimited resources.

5. There is a crisis of the anthropocentrism: human beings are not the center of universe. The "dominion on the earth" as it is written in the Creation Book of Genesis should be understood as a responsible stewardship.

It is clear that the Encyclical is not only a moral guide; it holds political considerations regarding the societal- 
environmental intersection and the socioeconomic system. This commitment is not random: Pope Francis envisioned a responsibility to global political issues even before becoming a Pontiff as, for instance, the one presented in a book offering an inter-faith dialogue with the Argentinian Rabbi Abraham Skorka some years ago. In regards to power and politics the Pope considered:

We are all called to a political action in building our nation. The preaching of human, religious values has a political connotation. Whether we like it or not, the challenge is to draw attention to these values without getting into party politics. (Bergoglio \& Skorka: 2013, p. 131)

Different reflections of the Encyclical emerged from the scientific community in terms of acceptance or criticism besides those from the Catholic Church itself. For example, Robert Stavins director of the Harvard Environmental Economics pointed out in an op-ed that the Pope was misguided when talking about the economic system and recommended some concepts of public policy. It is considered in the article that climate change is an unintended negative consequence of the industrial activity. Since the producers create goods and services that people want, consumers justify the activity. The conclusion is that "there may well be ethical dimensions of the problem, but it is much more than a simple consequence of some immoral actions by corrupt capitalists" (Stavins, 2016).

From a divergent starting point, it is considered that nobody in the planet is exempted to participate in the degradation of natural environments; even for its very existence as a consumer of non-renewable wealth. Nonetheless, participation does not mean liability. The communities that are not given the chance to generate an alternative way of livelihood exploit a resource as part of their basic survival. For that reason, this viewpoint considers that the "main agent of the destruction of nature is poverty", while the main source of pollution and depletion of natural resources is not individual consumption but the disproportionate use of energy (Buch, 2013, p.145). Similarly, Michael Löwi, an emeritus Research Director at the French National Center of Scientific Research, argues that the influence of the Catholic Church worldwide is a key contribution towards critical ecological consciousness. Moreover, it has an "anti-systemic analysis of the crises, connecting the inseparable social question with the protection of the environment" (Löwi, 2015, p. 50).

Overall, the first important remark of the Laudato Sí is the idea that the planet Earth is not human-centered. This is a transformative concept coming from the most important public figure of the Catholic Church. The switch from an anthropocentric to an eco-centric view of the world has new moral implications. 
If human beings are just part of a bigger landscape that includes other species, the appropriation of nature (as written in the Cenesis) switches the meaning to the idea of administration of resources. This is finally linked to a new vision of progress: resources are not indefinite and humans are not above all the ecosystem. Besides the diverse range of opinions regarding the Vatican's publication, it is clear that the current Pope intends to raise concern over a systemic crisis of values that have governed every day's life motivations for centuries. Although is too soon to underline the impact that these concepts could entail in the religious grounds of the Church, it has, at least, caused an impact on the public opinion.

A recent Survey conducted within the U.S. in November 2015 called it "The Francis Effect" underlining that after the Encyclical and the visit to the country, more North Americans trust the Pope as a source of information about global warming (+11 points); almost half $(45 \%)$ of the population and over half of Catholics (56\%) say they have seen, read, or heard media coverage about the Pope's view on the topic. The awareness of global warming due to the Pope's intervention proved also to generate an increase among the general public (+14 points). Nearly 1 out of 10 North Americans (9\%) and nearly 2 out of 10 Catholics (18\%) stated that the Pope`s ideas on global warming were discussed in their place of worship, and overall ( +6 points) people became more likely to discuss the subject with their friends and family. As a wider effect, many North Americans say the Pope's views on global warming influenced their own views (17\%) and Catholics in particular (35\%) considered that the Pope's position influenced their views about this (Maibach, Leiserowitz, RoserRenouf, Myers, Rosenthal \& Feinberg, 2015, p. 5).

The second observation of the Encyclical is the notion that inequality emerged from a "technocratic" model of economic growth, which underscores a critique of the ongoing socioeconomic system as such. The third point of the Letter refers to the social and environmental burden that developing countries confront to assure the development of richer nations. This statement can be therefore identified with a "popular environmentalism" in terms of the political option that a less industrialized nation has in the global economy. It is related to the base of human survival as to the environmentalism of livelihood and liberation ecology.

In his book "The Environmentalism of the Poor", Joan Martínez Alier (2007, pp. 35-36) explains that this popular environmentalism is related to environmental justice movements of developing countries who struggle against the environmental impacts that threaten the poor, who are the vast majority of population in these nations. It includes rural movements whose fields were destroyed by mining; 
artisanal fishers' movements opposed to industrial fishing that destroys their livelihoods and deplete fish banks. Additionally, it is related to movements against mines and factories by communities affected by pollution as a result of living downstream from these installations. All of the above takes the form of resistance to the foreign exploration of the environmental potential of the Continent, in the case of Latin America (Martínez Alier, 2007, p.280).

This approach is inevitably growing at a global level due to the increase of environmental conflicts related to unequal distribution. The two mainstreams in the environmentalism of the poor are wilderness thinking related to the cult or worship to wildlife, and scientific industrialism associated with the conviction of ecoefficiency, sustainable development, or ecological modernization (Martínez Allier, 2007, p.36). These lines are not mutually exclusive, but supporters of the cult to wildlife usually have a more conservationist approach to nature (preserve the resources untouched by humans) than those that care for a greener economy. Also, the first one is mostly based on moral thoughts whereas the second is predominately an economy-led concept.

The implementation of the environmental justice movement in developing countries is a complex issue. There are too many interests associated with the changes that are needed to tackle environmental catastrophes; so a number of companies provide funding aimed at discrediting scientists that forecast climate change as the result of human activity (Buch, 2013, p.140). Nonetheless, we assume that explanations should have a multifactorial approach: besides the existence of evident inequalities between countries in the North and the South, it is also a fact that within developing countries there are numerous political intersections that give a local meaning to climate change. Large-scale civil organizations, for example, have their own stakeholders so that they need to comply with a given agenda and can potentially act as lobby groups. As a result, some issues are followed in detriment of others that not necessarily are more urgent from a broader point of view; in parallel, local companies have their own corporative interests and policies; and, multinational companies that seek to develop their business in these nations independently take action as well. The reality is thus much more complicated than a systemic NorthSouth dichotomy.

So far, in Latin America the old doctrine of economic growth seems to be kept at any cost; so that "the environmentalism is treated as a luxury of the rich rather than as a necessity of the poor. Consequently, opportunities to present environmental conflicts are wasted". Mainly the oil exporting countries (like Venezuela) are those who refuse to discuss the 
greenhouse effect (Martínez Alier, 2007, p.167). As a consequence, the anti-environmentalist lobby is stronger in the South than in the North, and the intellectual reflection is driven or accompanied by local resistance. Every year thousands of environmental conflicts occur in these countries that are not reported. Inversely, in developed countries environmental movements mobilize policies in the government and conform a formal pressure group for the companies (Martínez Alier, 2007, pp. 276-277).

\section{Ecological Modernization or Business as Usual?}

Latin America has an extensive biodiversity potential. This natural advantage is offset by its dependence on the production of commodities and its derivatives. In other words, due to the development model based on agribusiness, Latin America is vulnerable to climate change in economic terms. At least there are two major groups of problems: first, there are fossil-fuel dependent economies such as Bolivia, Ecuador, Nicaragua and Venezuela (that would need alternative sources of growth). Second, there is a vast deforestation, contamination, and depletion of renewable and non-renewable resources in countries with a high biodiversity volume such as Brazil and Peru. However, both groups are not mutually exclusive; Amazon countries which include Bolivia, Ecuador, and
Venezuela are also the key source of natural resources. This amplifies the concern in terms of environmental damage.

As an example of the first problem, according to a World Bank's news report (World Bank, 2013, October $25^{\text {th }}$ ) Nicaragua has such an important amount of geothermic resources that can be called a "paradise of renewable energies". Although it is mentioned that the government's objective is to promote geothermic energy, still almost half of the energy currently produced $(42 \%)$ comes from oil-based bunker fuel.

The Climate Scope Index 2015 released by Bloomberg New Energy Finance illustrate that in terms of clean energy investment, out of 55 countries from Asia, Africa, and Latin America, Nicaragua only ranked 27 followed by Bolivia (29), Ecuador (31), and Venezuela (54). In other words, there is still a fragile command of low-carbon business, clean energy value chains, and greenhouse gas management in these countries in particular. It is important to recall that the three cases are highly dependable on the export of a few number of products from extractive industries; as a result, seeking clean energy sources could potentially risk their own economic survival, if the economic development strategy does not change.

As a second concern, up until 2009 the nine Amazon countries lost almost 1 
million square meters of forest, around $16 \%$ of their original cover. Particularly the Brazilian Amazonia has had annual forest loss during 1990-2005 of 2.8 million hectares (Hall, 2011, p. 185). At the same time, Brazil accounts for $5 \%$ of global greenhouse gas emissions, placing the country as the world's fourth largest polluter (an important amount of the emissions are due to deforestation). Estimates indicate that by $2030,55 \%$ of its Amazon rain forest will be affected by clearing, logging, drought, and fragmentation, generating a rise in temperature that will have severe consequences at a local, continental, and world level (Hall, 2011, p. 186).

In this second group of problems, climate change is expected to impact productivity and add additional demands for water, energy, and equipment along with adaptation and mitigation policies. Projections for most economic analyses demonstrate substantial economic losses as temperature increases beyond the equivalent of a $\mathrm{CO} 2$ replication (Adams, Hurd, Lenheart \& Leary, 1998, p. 29). This reinforces the need to determine (and tackle) the warming trend.

From an economic point of view, a possible approach to confront these challenges is ecologic modernization that entails ecologizing the economy and economizing the ecology. These are two parallel processes: the first is a conversion of technology and organizational approaches by focusing on the replacement of healing to preventive technologies. The economization of ecology introduces economic principles aimed at protecting the environment. At the macro level they label and promote a post-industrial stage to achieve a qualitative economic growth dedicated to the use of renewable resources, information, and products with high added value. At the micro level it incorporates environmentally-friendly technologies to reduce the impact of a process or product (Lenzi, 2005, pp. 71-73).

The remark on the post-industrial character seems to conceptually conceive an economic model that reduces the pollution (end-of pipe equipment) as a way to achieve a better care on the environment. This kind of preventive technologies can contribute to a lesser emission of greenhouse gases, but the underlying problem of unequal socioeconomic exchange between developed and developing nations is still prevalent. Environmental modernization entails, however, a strong state intervention; in other words, it assumes an environmentallyregulated economic approach.

As an example of ecologic modernization, Uruguay is a remarkable case of commitment with clean energy production and environmental protection. During the meeting in Paris, the Uruguayan's head of climate change policy (a 
job that is inexistent in many other countries) announced that $95 \%$ of its electricity is generated by renewable energy resources and the change took only a decade (The Guardian, 2015, December $\left.6^{\text {th }}\right)$. We support the idea that ecologic modernization is essential across the world but since most Latin American economies are dependable on the agroindustry, this should be a political priority in order to tackle current costs and assure resilience. At the same time, international financial institutions and intergovernmental organizations can play a significant role in promoting the investment.

As regards to carbon dioxide projections, Costa Rica is another example. Its government has set a standard of carbon neutrality by 2021 . Emissions will be reduced to the point that offsets are enough to cancel the remaining emissions without damaging economic development. Costa Rica has become the only tropical country to invert its rate of deforestation. The forest increased from $21 \%$ in 1987 to $52 \%$ in 2013. In this case, the largest part of the financial resources $(80 \%)$ to implement this reforestation policy came from a fuel tax (Castro, 2015).

In terms of promoting ecologic modernization in the corporative sector, two essential initiatives from multibillionaire companies that are interested in research and/or mitigation efforts can be mentioned. The Friends of the Fossil Fuel Subsidy Reform created in 2010 combines international organizations, governments, and companies. Among the supporters are five countries from Latin America: Costa Rica, Chile, Peru, Uruguay, and Colombia. International organizations are The World Business Council for Sustainable Development, the OECD, and the World Bank; and some of the companies are Tesla, The Prince of Wales's Corporate Leaders Group ${ }^{7}$, and The B Team ${ }^{8}$.

The Fossil Fuel Subsidy Reform Communiqué presented in the opening day of the UN Conference on Climate Change 2015 is aimed at claiming the elimination of subsidies to fossil fuels. The argument is that governments spend over $\$ 500$ billion of public resources a year to artificially keep domestic prices low. Removing the subsidies and promoting clean energy would reduce greenhouse gas emissions by $10 \%$ by 2050 and the resources could be re-invested in more urgent issues to vulnerable societies. The Prince of Wales's Group that promoted the initiative represents itself 23 companies

This business group is integrated by gsk, Coca-Cola Enterprises, 3M, Unilever, Phillips, United Technologies, and Jaguar-Land Rover.

8 The B Team was created by Richard Branson (owner of Virgin Group) and includes the Tata Group, the Broad Group China, Natura, Toms Shoe giver, Econet, and Professor Muhamad Yunus. 
that employs 2 million people and has revenues for 170 billion USD (The Prince of Wales's Corporate Leaders Group Press Release, 2015, December $4^{\text {th }}$ ).

Breakthrough Energy Coalition is the second example ${ }^{9}$. This group of enterprises argues that the risk-reward balance for early-stage investment in potential clean energy systems is unlikely to meet the market tests for venture capital. These companies are willing to make a commitment to promote new technologies motivated by big returns in the future and scale to a market-driven clean energy economy. Their proposal is to work with governments by funding basic and applied research and giving assessment on how to drive innovation from the lab to the marketplace (Breakthrough Energy Coalition, 2016, February, $13^{\text {th }}$ ).

The participation of multibillionaire companies was also questioned in terms of the intentions that CEOs and founders could have with these initiatives. Also, in what sense do they change the transportation of their products or transform production plants to make them eco-efficient. Apart from the discussion over possible motivations, it is important to consider this as a process, so that there is still relevance in any innovative step towards a more sustainable future. It is clear that cleaner energy models would have an important return in terms of revenues for these companies. However, depending on future outcomes it could also bring benefits for the global society as a result of a corporate social responsibility business strategy.

Ecological modernization and mitigation policies are certainly needed worldwide, but we argue that they should become especially significant for governments, scientific communities, and corporate leaders from Latin America. The possibilities of building such future is having political stability, fight corruption, and build public-private partnerships to create new technologies with a social viewpoint. This would possibly alleviate the consequences of the existing weather-related catastrophes, promote scientific research, and ecoefficient business.

At the same time, to favor social inclusion, economic growth, and climate change mitigation, Latin American nations would need to progressively change the model of "business as usual" based for the most part on extractive industries and export of commodities. That would entail

Supporters of the Breakthrough Energy Coalition include: Amazon, Virgin Group, Microsoft, Linkedin, Alibaba Group, Soros Fund, SAP-Germany, Sequoia Capital-China, Soft Bank Group-Japan, Tata SonsIndia, Hewlett Packard, Facebook, and the University of California 
a greener approach on economic planning and political commitments with their own societies. For instance, the problem of several environmental conflicts not being reported in these countries is not part of the NorthSouth unequal distribution of wealth, but rather a sign of political divorce between local communities and their governments.

\section{Conclusions}

Estimates from the Economic Commission for Latin America and the Caribbean (ECLAC, 2015, pp.8182) indicates that the economic cost of climate change in Latin America and the Caribbean will be between $1.5 \%$ and $5 \%$ of their GDP by 2050 . Emissions of $\mathrm{CO} 2$ only represents $9 \%$ of the global total. Efforts to mitigate greenhouse gas emissions have not yet achieved a significant progress although adaptation costs will represent less than $0.5 \%$ of GDP (with a high degree of uncertainty). This data is important in the sense that it quantifies the economic burden that would entail to seek ecologic modernization. It is pre-assumed that all strategies towards mitigation, adaptation, and research entail massive economic resources so that developing countries would never have access to conduct these changes. As the cases of Uruguay and Costa Rica proved, still some initiatives can be achieved in that line, only with a governmental long-term planning oriented to environmental sustainability.
As a general conclusion, it is clear that Latin America is highly vulnerable to climate change as a result of its socioeconomic conditions, the dependence on extractive industries and agribusiness, and the unfavorable relationship with countries in the North. That situation is so relevant for the present and future of Latin American nations that a political and mostly moral commitment from leaders from different sectors at every level, including local communities, should be expected.

Given the landscape of complexities in many developing nations, we identified two conceptual starting points to take action from the perspective of the environmentalism of the poor: the cult to wildlife usually expressed in resistance movements and other environmental justice approaches including the proclamation of the Encyclical Laudato Sí; and the ecological modernization focused in economic policies and public-private practices. Both standpoints seem mutually exclusive in terms of how global economic relations and its social consequences are conceived. In that case, we would discuss that there is a possible balance when public policies and corporate investment tackle the environmental burden imposed to developing nations and promote economic growth. A pragmatic environmentally sustainable approach would entail new ways of promoting development, a concerned citizenry regarding environmental issues, and a 
long-term design that involves building incentives and legal security for foreign investment in less industrialized nations.

In terms of prospective for social actors, the several stakeholders that have an active role in the rally against climate change would have to confront their own challenges: scientists need to keep making advances in the topic and address the question of how to build public concern out of environmental problems; large corporations should evaluate and commit to new investments in sustainable production and transport practices; the United Nations will have to scrutinize the compromise of nearly 200 countries that signed the COP21 Agreement; all governments face the political and human cost of climate-related disasters, pollution, and the need to comply with multilateral agreements. At the same time, developed nations should demonstrate "willingness to give what it takes" (O'Gara \& Mourato, 2015) to undertake mitigation and adaptation measures. Although global warming is a widespread public issue and a broadly accepted scientific fact, there are still many economic and political opposing interests to solve.

As a final remark, it is important to underline that climate change has also an impact in the international security situation. By the time people lose their livelihood, arable lands become scarce, and fresh water is inaccessible, social groups will likely turn to community violence as a battle for survival. In this landscape, armed non-state actors including insurgent groups will have a new source of insecurity to find new recruits and build their narratives (World Economic Forum, 2015, p.30). Thus, although environmental risks are a global concern, countries with more fragile institutions and less development are far more exposed to the consequences. This level of exposure is predominantly important in Africa and Latin America. It not only affects the prospects of economic growth; it also represents a multiplier factor of social conflicts.

Overall, climate change is becoming a widespread political issue of the mass public. According to the aforementioned surveys we conclude that the perception of seriousness is mostly related to self-identification with post-materialist notions and the commitment with religious services; but equally important is that it can be identified with personal emotions such as worry. In that regard, although scientific and economic considerations are clearly relevant, the subjective element in climate change ranks higher than expected. The intervention of the Argentinian Pope in the global political agenda by accepting the IPCC conclusions has at least invigorated that trend, and brought more worldwide public concern with the potential to be extended to new outcomes. 


\section{REFERENCES}

Adams, R., Hurd, B, Lenhart \& S, Leary. (1998). Effects of global climate change on agriculture: an interpretative review, Climate Research, 11, 19-30.

Beck, U. (2008) Quées la Globalización. Falacias del globalismo, respuestas a la globalización. Buenos Aires: Paidós.

Bergoglio, J.\& Skorka, A. (2013) Sobre el Cielo y la Tierra. Buenos Aires: Sudamericana.

Bloomberg New Energy Finance, Climate Scope Index 2015 [Data File] Retrieved from http://globalclimatescope.org/en/

Blue, G (2015): Framing Climate Change for Public Deliberation: What Role for Interpretive Social Sciences and Humanities? Journal of Environmental Policy \& Planning. 2-18. DOI: 10.1080/1523908X. 2015.1053107

Buch, T. (2013). Desarrollo y Ecopolítica. Los grandes debates de la tecnología, el ambiente y la sociedad. Buenos Aires: Universidad Nacional de Quilmes.

Brenkert-Smith, H., Meldrum, J. \& Champ, P. (2015) Climate change beliefs and hazard mitigation behaviors: homeowners and wildfire risk, Environmental Hazards, 14 (4), 341-360. DOI: 10.1080/17477891.2015.1080 656
Castro, R. (2015), Eco-Competitiveness and Eco-Efficiency: Carbon Neutrality in Latin America, Harvard Project on Climate Agreements, 1-12.

Centre for Research for the Epidemiology of Disasters \& The United Nations Office for Disaster Risk Reduction. UNISDR (2015). The Human Cost of Weather Related Disasters.1995-2015. Retrieved from http://www.unisdr.org/2015/ docs/climatechange/COP21 WeatherDisastersReport_2015_ FINAL.pdf

Chokshi, N. (2015, November 30) Pope Francis: The world is near 'suicide' on climate change; 'it's now or never'. The Washington Post. Retrieved from https:// www.washingtonpost.com/news/ worldviews/wp/2015/11/30/popefrancis-the-world-is-near-suicideon-climate-change-its-now-ornever/

Dunlap, R., Mitchelson, W. \& Stalker, G. (2002) Handbook of Environmental Sociology. U.S.A. Greenwood Press.

Dunlap, R. (2002) Environmental sociology: A personal perspective on its first quarter century. Organization \& Environment, 15 (1), 10-29.

Economic Commission for Latin America and the Caribbean, United Nations. (2015, February) The economics of climate change in Latin America and the Caribbean 
Paradoxes and challenges of sustainable development, Santiago de Chile.

Friends of the Fossil Fuel Subsidy Reform (2015, April) Communiqué. Retrieved from https://www.iisd. org/library/fossil-fuel-subsidyreform-communique

Graham-Harrison, E. (2015, December 6) Where Uruguay Leads, the rest of the world struggles to keep up. The Guardian. Retrieved from http://www.theguardian.com/ commentisfree/2015/dec/06/ uruguay-climate-change-reformprogress

Hall, A. (2011) GETTING REDDY. Conservation and Climate Change in Latin America, Latin American Research Review, Special Issue, 184-214.

Hanningan, J.( 2009) Sociologia Ambiental. São Paulo: Editora Vozes.

Infobae (2015, December, 12) El Papa Francisco advierte que el mundo está "al borde de un suicidio". Retrieved from http://www.infobae. com/2015/11/30/1773378-elpapa-francisco-advierte-que-elmundo-esta-al-borde-un-suicidio

Intergovernmental Panel on Climate Change, (2014). Climate Change 2014: Synthesis Report. Contribution of Working Groups I, II and III to the Fifth Assessment Report of the Intergovernmental Panel on Climate Change [Core Writing Team, R.K. Pachauri and L.A. Meyer (eds.)]. Geneva, Switzerland: IPCC.

Isdo, C., Carter, R. \& Singer, F. (2015, November 23), Why Scientists Disagree about Global Warming. The Heartland Institute. Non Profit Research Organization. Illinois. Retrieved from https://www. heartland.org/policy-documents/ why-scientists-disagree-aboutglobal-warming

Kvaløy, B., Finseraas, H., \& Listhaug, O. (2012) The publics' concern for global warming: A cross-national study of 47 countries, Journal of PeaceResearch,49(11),11-22.DOI: 10.1177/0022343311425841

LAUDATO SI'. Encyclical Letter of The Holy Father Francis on Care for our Common Home (2015) Vatican Press.

Lenzi, C. (2006) Sociologia Ambiental. Risco e sustentabilidade na modernidade. São Paulo: ANPOCS.

Löwy, M., (2015) Laudato Sí - The Pope's Anti-Systemic Encyclical. Monthly Review, 67 (7), 50-54.

MC Kalin, V. (2015, October 25) Global warming is a big fat lie and the science behind it is fake: John Coleman. Tech Times. Retrieved from http://www.techtimes.com/ articles/18641/20141025/globalwarning-is-a-big-fat-lie-and-thescience-behind-it-is-fake-johncoleman.htm 
Maibach, E., Leiserowitz, A., RoserRenouf, C., Myers, T., Rosenthal, S. \& Feinberg, G. (2015) The Francis Effect: How Pope Francis Changed the Conversation about Global Warming. George Mason University and Yale University. Fairfax, Virginia: George Mason University Center for Climate Change Communication.

Martínez Alier, J.(2012)O Ecologismo Dos Pobres, São Paulo: Editora Contexto.

Mathiesen, K. (2015, December 2) Where is the world's most polluted city? The Guardian. Retrieved from http://www.theguardian.com/ cities/2015/dec/02/where-worldmost-polluted-city-air-pollution

Moreno, L.A., (2010) To Tackle CO2, Start with H2O: How Latin America's Water Problems Could Affect Climate Change Negotiations. The Fletcher Forum of World Affairs, 34 (2). 119-125.

Myers TA, Maibach, E., Peters E. \& Leiserowitz, A. (2015) Simple Messages Help Set the Record Straight About Scientific Agreement on Human-Caused Climate Change: The Results of Two Experiments. PLoSONE10 (3), Sweden. DOI:10.1371/journal. pone.0120985

Naciones Unidas (2015, Diciembre) Convención Marco sobre el Cambio Climático. Conferencia de las Partes. 21er Periodo de Sesiones. Paris. COP21.
NASA (2015, December 4) Climate Change. How do we know? Global Climate Change. Vital Signs of the Planet. Retrieved from http:// climate.nasa.gov/evidence/

O'Garra, T., \& Mourato, S. (2015): Are we willing to give what it takes? Willingness to pay for climate change adaptation in developing countries, Journal of Environmental Economics and Policy, 1-16. DOI: 10.1080/21606544.2015.1100 560

Smith, N., \& Leiserowitz, A. (2014) The Role of Emotion in Global Warming Policy Support and Opposition, Risk Analysis, 34:5, 937-948. DOI: 10.1111/risa. 12140

Stavins, R. (2016). Are the Pope's Critiques of Markets on Point or Somewhat Misguided? Environmental Law Institute, January- February, Washington DC.

Sherwell, P. (2011, September 25) War of words over global warming as Nobel laureate resigns in protest. The Telegraph. Retrieved from http://www.telegraph. co.uk/news/earth/environment/ climatechange/8786565/War-ofwords-over-global-warming-asNobel-laureate-resigns-in-protest. html

The Prince of Wales's Corporate Leaders Group (2015, December 4) Press Release. Paris Climate Change Conference opens with unprecedented call by governments and businesses to end fossil fuel 
subsidies. Retrieved from http:// www.corporateleadersgroup. com/resources/news-items/parisclimate-change-conferenceopens-unprecedented-callgovernments-businesses-endfossil-fuel-subsidies

The Governor's Office of Planning and Research, State of California OPCRA. (2016). Scientific Organizations That Hold the Position That Climate Change Has Been Caused by Human Action. Retrieved from https://www.opr. ca.gov/s_listoforganizations.php

The World Bank (2013, October 25) Nicaragua: a renewable energy paradise in Central America, Press Release.

Tornielli, A. (2015, November 30) El Papa sobre el clima: "o se cambia ahora o nunca más. Estamos al borde de un suicidio". Vatican Insider. Retrived from http:// www.lastampa.it/2015/11/30/ vaticaninsider/es/vaticano/ el-papa-sobre-el-clima-o-secambia-ahora-o-nunca-msestamos-al-borde-de-un-suicidior4hx92r1SxJ3bxqk2lxqMP/pagina. html

U.S. Department of State, Office of the Spokesperson (2015, November 30). Joint Statement on the donors' pledge of \$248M USD to the Least Developed Countries Fund to support climate change adaptation.

Wike, R. (2015) What the World Thinks about Climate Change in
7 Charts. Pew Research Center Survey. Retrieved from http:// www.pewresearch.org/facttank/2015/11/05/what-the-worldthinks-about-climate-change-in-7charts/

World Economic Forum (2016) The Global Risks Report 2016.11 th Edition. Insight Report.

World Health Organization, Burden of Disease from Ambient Air Pollution for 2012. Retrieved from http:// www.who.int/phe/health_topics/ outdoorair/databases/AAP_BoD_ results_March2014.pdf?ua=1 